\title{
The Relationship of Eating Habits, Physical Activities, Food Choises with Obesity among Students in Public Senior High School Medan
}

\author{
Vera Chitra Dewi Saragih ${ }^{1}$, Etti Sudaryati ${ }^{2}$ \\ Department of Public Health Nutrition \\ Faculty of Public Health, University of Sumatera Utara \\ Medan, Indonesia \\ veracdsaragih@gmail.com, etysudaryati@gmail.com
}

\author{
R. Kintoko Rochadi ${ }^{3}$ \\ Department of Public Health Promotion \\ Faculty of Public Health, University of Sumatera Utara \\ Medan, Indonesia \\ kintokorochadi@hotmail.com
}

\begin{abstract}
The prevalence of obese adolescents aged 16-18 in Indonesia is $1.6 \%$, in North Sumatra Province is $1.4 \%$, and in Medan is $3.18 \%$. In school children, the incidence of obesity becomes a serious problem because it will continue until they grow up. The purpose of this research was to analyze the relationship of eating habits, physical activities and food choices with obesity among high school students. This research was an analytic research with case control design. Population were students of Public Senior High School 3 (SMA Negeri 3) Medan. Sample size based on observational research formula with case control design were 70 obese students and 70 students who are not obese. The independent variables were eating habits, physical activity, food choices, while dependent variable was obesity. Data was collected by using the questionnaire and statistically analyzed using chi-square test. All independent variables were significantly associated $(p<0.05)$ and risk factors for obesity in adolescent, eating habits $(O R=2.72$; $C I$ : 1.37 to 5.41$)$; physical activities $(O R$ $=2.40$; CI: 1.02 to 5.59$)$; food choices $(\mathrm{OR}=2.90$; $\mathrm{CI}$ : 1.45 to 5.81 . It meant that there was a significant relationship of eating habits, physical activities, food choices with obesity.
\end{abstract}

Keywords - eating habits; physical activities; food choices; obesity; students

\section{INTRODUCTION}

The prevalence of obesity globally increase every year, even obesity has nearly tripled since 1975 . According to World Health Organization (WHO) more than 1.9 billion adults, 18 years and older were overweight and over 650 million of them were obese in 2016. The prevalence of population age $>18$ years are $39 \%$ overweight, which is $11 \%$ of men, and $15 \%$ are women. Over 340 million children and adolescente aged 15-19 were overweight or obese in 2016. This number was risen from $4 \%$ in 1975 to over $18 \%$ in 2016 [1]. World Obesity Federation (WOF, 2015) reported that in Southeast Asia there were $2.6 \%$ of men and $1.5 \%$ women in the age group 14-17 years who were obese [2].

Basic Research 2013 showed that the prevalence of obesity in adolescent aged 16-18 years is $1.6 \%$ [3]. The prevalence of obesity in adolescents in North Sumatera Province was $1.4 \%$ and the prevalence of obesity for the population aged $>15$ years in Medan is 3.18\% [4].

Adolescents have special nutritional needs, because at that moment the rapid growth and the changes of physiological maturity were occured. Changes in adolescence will influence the needs, absorption, as well as the use of nutrients. Hormonal changes following puberty also causes many physiological changes that affect nutritional needs of teenagers. The period of the great nutritional needs is on the teen between the ages of 12-15 years in males, and 10-13 years in women [5].

Many nutritional problems are faced by adolescents like obesity, anemia and anorexia nervosa. Studies on nutritional status in adolescence needs to be done because during this period the risk of nutritional disorders is highly occured. One of the most frequent nutritional problems experienced by adolescents is obesity. Obesity in adolescents should be highly considered as a serious problems because it can affect their life when they are adult. Obesity is a risk factor for several non communicable diseases like diabetes and cardiovascular.

Obesity can also influence the quality of life. A research conducted among junior high school students in Jakarta showed that the quality of obese adolescents' life was lower than normal adolescents, with $\mathrm{p}=0.01$. The quality of obese adolescents' life was lower in both physical and psychosocial functions (emotion, social, and school function) [6].

A way to determine the nutritional status in teenagers is by measuring the body mass index (BMI) of the teenagers. BMI can help identify teens who have experienced overweight. BMI can be calculated using the following formula:

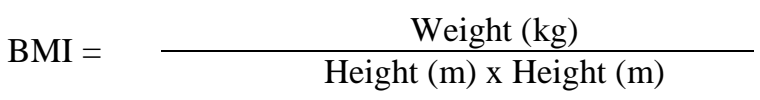

The assessment of nutritional status of adolescent are determined based on BMI by age in accordance with standards of the WHO [7]. The categories can be seen in the Table 1 below: 
TABLE I

CATEGORIES AND CHILD NUTRITIONAL STATUS TRESHOLD AGE 5-18 YEARS BASED ON BMI INDEX BY AGE

\begin{tabular}{|c|c|}
\hline The Category & Nutritional Status Threshold \\
\hline Vey Skinny & $<-3$ SD \\
\hline Skinny & -3 SD up to $<-2$ SD \\
\hline Normal & -2 SD up to +1 SD \\
\hline Overweight & $>1$ SD up to +2 SD \\
\hline Obesity & $>+2$ SD \\
\hline
\end{tabular}

There are many factors influencing the incidence of obesity and several researches were conducted to reveal them. A research in Surabaya showed that knowledge, physical factors, and the rate of consumption of carbohydrates is the most dominant factor against the risk of the occurrence of obesity [8]. A similar study conducted among senior high school students in Yogyakarta mentioned that several factors that affect the occurrence of obesity in teenagers were energy, fat, carbohydrate, the frequency of fast food and the breakfast intake [9]. Research in Semarang showed that frequency of snack and physical activity affected the incidence of obesity in adolescent [10].

Regarding the impact of the risks that can be caused by obesity then precautionary measures is an important thing to do. Knowing their risk factors of obesity, it is expected to do intervention program to prevent obesity especially in adolescent.

SMA Negeri 3 is a public senior high school. This school is one of the favorit schools in Medan. The survey in SMA Negeri 3 Medan found the prevalence of obesity is a 3,91\%. This research aimed to analyze the relationship of eating habits, physical activities, food choices with obesity among high school students.

\section{MATERIAL AND METHODS}

This research was the analytic research with case control design. Research conducted from May to November 2017 in SMA Negeri 3 Medan. The population in this research were the students of SMA Negeri 3 Medan. The samples on this research were 140 students with case group were 70 students and control group were 70 students. This sampling was based on case control design sampling formula with a comparison of case and control is 1:1. Inclusion criteria for the group of cases are students with BMI index by age are $>+2 \mathrm{SD}$. The students also are willing to be respondents by signing informed consent. The inclusion criteria for the control group students are normal with $\mathrm{BMI}$ index by age are $-2 \mathrm{SD}$ to $+1 \mathrm{SD}$ and also willing to be respondents by signing informed consent.

The data about eating hbits, physical activities, and food choices were collected by distributing the questionnaires to respondents. The collected data was analyzed statistically by Chi-Square test with a confidence level of $95 \%$ and Odds Ratio (OR).

\section{RESULTS}

\section{A. Characteristic of Subjects}

Based on table II, it can be seen that the parents of obese students who are working are more than not working, while parents of non obese students who are not working are more than working. The education of students' parents either obese or non obese are commonly completed Junior High School above. Table II also showed that the income of students' parents is almost the same in every level of income, either in obese students and non-obese.

TABLE II

CHARACTERISTIC OF SUBJECTS

\begin{tabular}{|c|c|c|c|c|}
\hline \multirow{3}{*}{ Characteristic } & \multicolumn{4}{|c|}{ Obesity Status } \\
\hline & \multicolumn{2}{|c|}{ Obesity } & \multicolumn{2}{|c|}{ Non Obesity } \\
\hline & $\mathbf{N}$ & $\%$ & $\mathbf{N}$ & $\%$ \\
\hline \multicolumn{5}{|l|}{ Father's occupation } \\
\hline Government officers & 14 & 20 & 14 & 28 \\
\hline Indonesian Army & 8 & 11.4 & 5 & 7.1 \\
\hline Private Employee & 18 & 25.7 & 15 & 21.4 \\
\hline Self Employee & 17 & 24.3 & 21 & 30 \\
\hline Others & 11 & 15.7 & 13 & 18.6 \\
\hline Does not work & 2 & 2.9 & 2 & 2.9 \\
\hline \multicolumn{5}{|l|}{ Mother's occupation } \\
\hline Government officers & 10 & 14.3 & 11 & 15.7 \\
\hline Indonesian Army & 0 & 0 & 0 & 0 \\
\hline Private Employee & 6 & 8.6 & 5 & 7.1 \\
\hline Self Employee & 14 & 20 & 9 & 12.9 \\
\hline Others & 26 & 37.1 & 8 & 11.4 \\
\hline Does not work & 14 & 20 & 37 & 52.9 \\
\hline \multicolumn{5}{|l|}{ Father's education } \\
\hline Uneducated & 0 & 0 & 0 & 0 \\
\hline Completed Elementary & 0 & 0 & 0 & 0 \\
\hline Completed Junior High School & 1 & 1.4 & 2 & 2.9 \\
\hline Completed Senior High School & 22 & 31.4 & 27 & 38.6 \\
\hline
\end{tabular}




\begin{tabular}{|l|c|c|c|c|}
\hline Completed Academy/University & 47 & 67.1 & 41 & 58.6 \\
\hline Mother's Education & & & & \\
\hline Uneducated & 0 & 0 & 0 & 0 \\
\hline Completed Elementary & 0 & 0 & 0 & 0 \\
\hline Completed Junior High School & 2 & 2.9 & 2 & 2.9 \\
\hline Completed Senior High School & 29 & 41.4 & 35 & 50 \\
\hline Completed Academy/University & 39 & 55.7 & 33 & 47.1 \\
\hline Parent's income (in Rupiahs) & & & & \\
\hline$<2,000,000$ & 2 & 2.9 & 5 & 7.1 \\
\hline $2,000,000-3,000,000$ & 15 & 21.4 & 14 & 20 \\
\hline $3,000,000-5,000,000$ & 29 & 41.4 & 31 & 44.3 \\
\hline$>5,000,000$ & 24 & 34.3 & 20 & 28.6 \\
\hline
\end{tabular}

TABLE III

RELATIONSHIP OF EATING HABITS, PHISICAL ACTIVITY AND FOOD CHOICES WITH OBESITY

\begin{tabular}{|c|c|c|c|c|c|c|}
\hline \multirow{2}{*}{ Risk Factors } & \multicolumn{2}{|c|}{ Case } & \multicolumn{2}{|c|}{ Control } & \multirow{2}{*}{ p value } & \multirow{2}{*}{$\begin{array}{c}\text { OR } \\
(95 \% \mathrm{CI})\end{array}$} \\
\hline & $\mathbf{N}$ & $\%$ & $\mathbf{N}$ & $\%$ & & \\
\hline \multicolumn{7}{|l|}{ 1. $\quad$ Eating Habits } \\
\hline a. Bad & 47 & 67.1 & 30 & 42.9 & \multirow[t]{3}{*}{0.006} & \multirow{3}{*}{$\begin{array}{c}2.72 \\
(1.37-5.41)\end{array}$} \\
\hline b. Good & 23 & 32.9 & 40 & 57.1 & & \\
\hline Total & 70 & 100 & 70 & 100 & & \\
\hline \multicolumn{7}{|l|}{ 2. $\quad$ Physical Activity } \\
\hline a. Light & 60 & 85.7 & 50 & 71.4 & \multirow[t]{3}{*}{0.038} & \multirow{3}{*}{$\begin{array}{c}2.40 \\
(1.02-5.59)\end{array}$} \\
\hline b. Moderate & 10 & 14.3 & 20 & 28.6 & & \\
\hline Total & 70 & 100 & 70 & 100 & & \\
\hline \multicolumn{7}{|l|}{ 3. Food Choice } \\
\hline a. Bad & 40 & 57.1 & 22 & 31.4 & \multirow[t]{3}{*}{0.004} & \multirow{3}{*}{$\begin{array}{c}2.90 \\
(1.45-5.81)\end{array}$} \\
\hline b. Good & 30 & 42.9 & 48 & 68.6 & & \\
\hline Total & 70 & 100 & 70 & 100 & & \\
\hline
\end{tabular}

\section{B. Relationship of Eating Habits, Physical Activity and Eating Patterns with Obesity}

The result of the test shows that eating habits, physical activity and food choices were associated with obesity as described in table III. This was indicated by $\mathrm{p}$ value $(\mathrm{p}<0.05)$ for all variables. Refer to the odds ratio (OR) value, students who have bad eating habits are 2.72 times in higher risk of obesity compared with students who have good eating habits. Students who did light physical activity were 2.40 times in higher risk of obesity compared to students who did moderate physical activities. Students who had bad food choices were at risk of 2.90 times of being obesed compared with students who had good food choices.

1) Eating Habits: The term of eating habits refers to why and how people eat, what they eat, and with whom they eat, as well as the ways to obtain, store, use, and discard food. This research indicates that eating habits are associated with obesity $(\mathrm{p}=0,006)$. It was found that most students have habits of eating less like often not having breakfast, less consumption of vegetables and fruits, and often snacking. These results are in line with research in SMA Semen Padang that showed a correlation between eating habit with obesity [11]. The study of Jenny et al, among obese school children of Mexico City found that eating habits were associated with the risk obesity [12].
2) Physical Activity: Physical activity is defined as any bodily movement produced by skeletal muscles that requires energy expenditure. This research showed that there was a relationship between physical activity and obesity $(\mathrm{p}=0.038)$. This was caused by light physical activity done by students both in school and home. These results were in line with the research in Iran. The research indicated a significant relationship between activities of school-aged children in Zahedan, Iran with BMI as indicator of nutritional status [13]. Other research in Yogyakarta also showed that physical activity was related with overweight / obesity among teenagers [14]

3) Food Choice: Food choice refers to how people choose the food they eat. Many factors influence a person to choose the food that will be consumed like environmental factors, the food itself and individuals (consumers). This research shows a relationship between food choice and obesity $(p=0,004)$. The students prefer high energy content of food such as processed foods and sweet food. Food processing that selected generally are deep frying and baked. In addition, consumption of vegetables and fruit is also low. This result is also in line with several studies. The research of Azzrimaidaliza in adolescents of West Sumatera showed that teenagers have not varied in choosing the food they consumed. Generally the way of food processing more prefered by teenagers is fried, sauteed, and baked [15]. These kinds of food make the teenagers are risk of being obesed. Consuming variated food can meet the nutritional needs. Study in Iran found that consuming some 
certain food groups (i.e. vegetables, fruits, legumes and dairy products) may decrease the risk of obesity [16].

\section{CONCLUSIONS}

There is relationship of eating habits, physical activities, food choices with obesity in SMA Negeri 3 Medan. Preventing the obesity among the students by doing the intervention programs refer to eating habits, physical activities, and food choises is very important. Health promotion among the students can be done by giving more informations about nutrition to the students. School and parents should get involved in this program.

\section{ACKNOWLEDGMENT}

I want to thank the Principal of SMA Negeri 3 Medan for allowing this research to be conducted. I want also to thank all teachers and students for their cooperations and supports during this research.

\section{REFERENCES}

[1] WHO. (2017) Obesity and overweigth. [Online]. Available: http://www.who.int/mediacentre/factsheets/fs $311 / \mathrm{en} /$

[2] (2015)Prevalence \% Overweight and Obesity by WHO Region by Gender and Age (using IOTF International Cut off Points). [Online]. https://www.worldobesity.org/data/obesity-datarepository/resources/tables/19/

[3] Badan Litbangkes, "Riset Kesehatan Dasar 2013", Kementerian Kesehatan Republik Indonesia, 2014

[4] Dinas Kesehatan Provinsi Sumatera Utara, " The Health Profile of North Sumatera," 2013

[5] Poltekes Kemenkes Jakarta, Kesehatan Remaja: Problem dan Solusinya, Jakarta, Salemba Medika, 2010.

[6] D. Khodijah, E. Lukman, M. Munigar, "Obesitas dan Kualitas HidupRemaja", Jurnal Health Quality, Vol. 3 No. 2, Hal.69-140, Mei 2013

[7] I. D. N. Supariasa, B . Bakir, I. Fajar, Penilaian Status Gizi, 2nd ed, E. Rezkina, C. A.Agustin, Ed. Jakarta, Indonesia: EGC, 2016.

[8] Salamah Umi, "Faktor Yang Berhubungan Dengan Kejadian Obesitas Pada Remaja Sekolah Menegah Atas di Kawasan Surabya Pusat, " thesis, Airlangga University, Surabaya, Indonesia, 2011

[9] Kurdanti, et.al," Faktor-faktor yang mempengaruhi kejadian obesitas pada remaja", Jurnal Gizi Klinik Indonesia, vol. 11, pp. 179-190, April 2015

[10]S. Nur Aini, "Faktor Risiko Yang Berhubungan Dengan Kejadian Gizi Lebih Pada Remaja di Perkotaan," Unnes Journal of Public Health, vol .2 (1), Januari, 2013

[11]Indah, Sri Maharani, "Hubungan Kebiasaan Makan, Aktivitas Fisik dan Tingkat Stres dengan Obesitas Pada Remaja di SMA Semen Padang, " Diploma thesis, Nursing Faculty, Andalas University, Indonesia, 2015

[12] Jenny, et al, "Food habits, physical activities and sedentary lifestyle of eutropic and obese school children : a case contol study," BMC Public Health, 2015

[13] Keykhaei Faetemeh, Shahraki Mansour, Sargolhosseinzadeh, Sharaki Touran, and Dashipour Alireza, "Correlation of Body Mas Index and Physical Activity Among 7 to 11 Year Chidren at Zahedan, Iran," Food and Nutrition Bulletin, vol. 37(3), pp. 364-374, 2016

[14]S. V. Kurdaningsih, T. Sudargo, L. Lusmilasari, "Physical activity and sedentary lifestyle towards teenagers' overweight/obesity status," International Journal of Community Medicine and Public Health, vol. 3, pp. 630-635, March 2016

[15] Azrimaidaliza, Idral Purnakarya, "Analisis Pemilihan Makanan pada Remaja di Kota Padang, Sumatera Barat," Jurnal Kesehatan Masyarakat Nasional, vol.6(1), pp. 17-22, August 2011

[16] Saeed Dastgiri, Reza Mahdavi, Helda TuTunchi and Elnaz Faramarzi, "Prevalence of obesity, food choices and socio-economic status: a cross- sectional study in the north-west of Iran," Public Health Nutrition: vol.9(8), pp .996-1000,.2006 